\title{
STRATEGI PENGEMBANGAN INDUSTRI KREATIF UNTUK INOVASI
}

\section{CREATIVE INDUSTRY DEVELOPMENT STRATEGY FOR INNOVATION}

\author{
Hesty Heryani $^{\left.1^{*}\right)}$, Agung Cahyo Legowo ${ }^{1)}$, dan Indra Prapto Nugroho ${ }^{2)}$ \\ ${ }^{1)}$ Department of Agro-industrial Technology, Faculty of Agriculture \\ University of Lambung Mangkurat, Banjarbaru 70714, Indonesia \\ *email: hheryani@ulm.ac.id \\ ${ }^{2)}$ Department of Psychology, Faculty of Medicine, University of Sriwijaya, Indralaya, Indonesia \\ Makalah: Diterima 17 November 2020; Diperbaiki 17 Desember 2020; Disetujui 20 Desember 2020
}

\begin{abstract}
Changes are very fast and full of uncertainty, such as the current condition of COVID-19, which makes it very difficult for supply chain managers even though they already have a very good regularity. Changes in consumer preferences are very fast and even difficult to predict. The purpose of research and development was to identify the factors that influence the performance and competitiveness of the creative industry for innovation. It needed to be informed that the development strategy was not only providing information, availability of goods, money, and innovation, but there were pluses in terms of developing knowledge, knowing the strength map, implementing efficiency accompanied by value. Analysis of Strengths, Weaknesses, Opportunities, and Threats (SWOT) was used in determining alternative strategies, while the analysis focus strategy used the Quantitative Strategic Planning Matrix (QSPM) method by considering the Total Attractiveness Scores obtained. For this reason, the potential and challenges in a series of processes (transformation activities and transaction activities) of a product must be carefully scrutinized, so that added value can be created at each stage. The results of the SWOT analysis resulted in five alternative strategies, which were then followed by a QSPM analysis to obtain the total attractiveness scores. The results of the analysis gave the highest total value on the importance of potential resource availability with a value of 15.862 followed by the second to fifth order, the need to understand rapid market changes (14.840), build partnerships (14.646), standardized and sustainable products (14.123) and develop efficiency principles for competitiveness (12.288), respectively. Recommendations are given that resource potential and rapid response to market demands in addition to the other three factors should be considered in the development strategy for innovation in creative industries.
\end{abstract}

Keyword: COVID-19, innovation, SWOT, QSPM, total attractiveness scores

\section{ABSTRAK}

Perubahan sangat cepat dan penuh ketidakpastian seperti terjadi pada kondisi COVID-19 sekarang sangat menyulitkan pengelola rantai pasok walau sudah memiliki keteraturan yang sangat baik. Perubahan preferensi konsumen sangat cepat dan bahkan sulit diprediksi. Tujuan penelitian dan pengembangan adalah pada mengidentifikasi faktor-faktor yang berpengaruh pada kinerja dan daya saing industri kreatif untuk inovasi. Perlu diinformasikan bahwa strategi pengembangan tidak sekedar memberikan informasi, ketersediaan barang, uang serta adanya inovasi, tetapi ada plus dari sisi berkembangnya pengetahuan, mengetahui peta kekuatan, menerapkan efisiensi disertai adanya value. Analisis Strengths, Weaknesses, Opportunities, and Threats (SWOT) digunakan dalam menentukan alternatif strategi, sementara untuk strategi fokus analisis menggunakan metode Quantitative Strategic Planning Matrix (QSPM) dengan memperhatikan total attractiveness scores yang diperoleh. Untuk itu potensi dan tantangan dalam rangkaian proses (aktivitas transformasi maupun aktivitas transaksi) suatu produk harus dicermati dengan baik, sehingga dapat tercipta nilai tambah pada setiap tahapan. Hasil analisis SWOT menghasilkan lima alternatif strategi, yang kemudian dilanjutkan dengan analisis QSPM untuk memperoleh nilai ketertarikan total (total attractiveness scores). Hasil analisis memberikan nilai total tertinggi pada pentingnya ketersediaan sumberdaya potensial dengan nilai 15,862 dilanjutkan dengan urutan kedua hingga ke lima masingmasing adalah perlunya memahami perubahan pasar dengan cepat $(14,840)$, membangun kemitraan $(14,646)$, produk terstandar dan berkelanjutan $(14,123)$, serta mengembangkan prinsip efisiensi untuk daya saing $(12,288)$. Rekomendasi yang diberikan adalah potensi sumber daya dan tanggap cepat atas permintaan pasar selain ke tiga faktor lainnya harus menjadi perhatian dalam strategi pengembangan untuk inovasi pada industri kreatif.

Kata kunci : COVID-19, inovasi, SWOT, QSPM, total attractiveness score

\section{PENDAHULUAN}

Berbagai aktivitas pada sektor bisnis, secara global mengalami penurunan akibat pandemi Covid19. Kondisi tersebut juga mempengaruhi manajemen rantai pasok secara operasional di lapangan. Sistem yang terintegrasi serta mampu mensinkronkan serangkaian proses bisnis mulai dari bahan mentah yang berasal dari berbagai Supplier hingga kegiatan pemasokan produk berlanjut pada aktivitas distribusi

*Penulis Korespodensi 
hingga sampai ke konsumen untuk meningkatkan efisiensi operasional, profitabilitas, dan posisi kompetitif perusahaan serta mitra disebut sebagai managemen rantai pasok (Kozlenkova et al., 2015).

Kegiatan industri harus tetap berlangsung dan dapat memberikan nilai tambah (value), sehingga menghasilkan kinerja rantai pasok tetap berjalan secara lancar. Sangat penting bagi industri untuk mencari strategi baru mengenai manajemen rantai pasokan untuk bertahan dalam iklim bisnis yang kompetitif dan berubah-ubah saat ini (Saqib et al., 2019).

Sektor perekonomian pada mall dan pusat perbelanjaan mengalami penurunan daya beli masyarakat akibat Pandemi COVID-19. Akses teknologi memiliki peran terhadap ketersediaan dan kecepatan koneksi internet yang bermanfaat sangat besar bagi karyawan dalam menerapkan program Work From Home (WFH) oleh beberapa Perusahaan dan Pemerintah dengan mengalokasikan jam kerja pegawai lebih fleksibel tanpa membuang waktu untuk pergi dan pulang dari tempat kerja. Pembukaan kembali pusat perbelanjaan dan mall meningkatan kinerja dengan menerapkan penerapan social berskala besar (PSBB) untuk tetap memenuhi permintaan konsumen berdasarkan fashion dan mode memanfaatkan online shop melalui media siosial dalam strategi menghadapi kebiasaan baru dengan perubahan positif dalam kinerja transportasi barang sampai ke konsumen.

Berdasarkan data Direktorat Jenderal Perhubungan Darat Tahun 2020 terjadi peningkatan transaksi online shop sebesar 12 juta dibandingkan pada tahun 2019 yang hanya sebesar 3,1 juta sampai 4,8 juta. Menurut Elrhim dan Elsayed (2020) sekarang adalah waktu yang tepat bagi sektor $e$ commerce untuk menyelamatkan ekonomi dunia dari pengaruh penyebaran COVID-19 di pasar dan melakukan intervensi dan vitalitas untuk membuktikan pentingnya dan efektivitasnya $e$ commerce di bidang perdagangan dan belanja online.

E-commerce di Indonesia telah menjadi norma sosial yang berkembang dengan penggunaan platform online produk perawatan kesehatan, produk makanan beku, produk kerajinan, barang elektronik dan layanan internet seperti indihome menjadi pembeli online 85 juta dibandingkan sebelum COVID-19 yaitu 75 juta (Saragih et al., (2020).

Selain itu, market place yang dikembangkan melalui layanan e-commerce akan lebih cepat dalam melakukan penawaran produk dengan segala keunikannya, untuk dapat memenangkan dalam persaingan global dengan mengimplementasikan less contact ekonomi ke masyarakat khususnya Mitra.

Logistik dan distribusi dalam hal penyediaan pasar modern dan pasar online yang mengalami perubahan dalam rantai suplai produk untuk memastikan kualitas dari sisi konsumsi, mode transaksi menggunakan plaform digital. Mobilisasi penyedia layanan logistik sepanjang rantai suplai berkaitan erat dengan pengiriman dan pergudangan serta melibatkan produsen, distributor, pengecer, dan konsumen. Menurut Saragih et al. (2020) penggunaan Information and Communication Technology (ICT) membantu distribusi logistik dan pengiriman pada kegiatan transportasi. Struktur rantai suplai berubah mengikuti lokasi, kapasitas produksi, proses produksi, dan lokasi pergudangan yang mampu beradaptasi sebagai sistem di new normal. Pengembangan Industri kreatif melalui Usaha Mikro dan Kecil Menengah (UMKM) berbasiskan kreatifitas dan pemanfaatan Information Technology berdasarkan potensi lokal wilayah serta perubahan preferensi konsumen sangat cepat dan bahkan sulit diprediksi dapat menjadi peluang bisnis bagi UMKM bangkit.

Tujuan kajian dan pengembangan adalah mengidentifikasi faktor-faktor yang berpengaruh pada kinerja dan daya saing industri kreatif untuk inovasi, untuk kemajuan dan pengembangan pada new normal berbasis teknologi informasi. Tujuan lainnya dari sisi sociopreneur adalah penyampaian dan diseminasi pengetahuan terkait berfikir kritis dan membangun solidaritas Tim serta selalu mengevaluasi peta kekuatan dalam menghadapi persaingan global disertai efisiensi dalam value bisnis yang terukur.

\section{METODE PENELITIAN}

\section{Penentuan Lokasi Kajian Riset}

Penentuan lokasi kajian menerapkan metode judgement sampling dalam pemilihan sampel berdasarkan penilaian terhadap beberapa karakteristik anggota sampel (Anggito dan Setiawan, 2018). Kajian riset ini merupakan penelitian eksploratif untuk menggali potensi dan tantangan dalam rangkaian proses (aktivitas transformasi maupun aktivitas transaksi) suatu produk harus dicermati dengan baik, sehingga dapat tercipta nilai tambah pada setiap tahapan.

Kajian riset dilakukan pada Bulan AgustusOktober 2020 dengan melibatkan 2 (dua) Mitra yaitu Kelompok Pengrajin Purun Galoeh Bandjar dan Kelompok Pengrajin Purun Al Firdaus yang bertempat di Kelurahan Palam, Kecamatan Cempaka, Kota Banjarbaru, Kalimantan Selatan.

\section{Penentuan Responden}

Penentuan responden untuk perumusan strategi diambil dari Stakeholder yang merupakan Pakar dan memahami keberadaan kedua industri kreatif Mitra. Para Pakar dari sinergi kemitraan PENTAHELIX yang dibangun meliputi Akademisi, Bisnis, Goverment, Comunity dan Media (ABGCM) yang berada di Kota Banjarbaru dan sekitarnya, termasuk dari Provinsi Kalimantan Selatan.

\section{Metode Pengumpulan Data}

Data diperoleh melalui wawancara langsung dengan pihak-pihak terkait atau pakar di lapangan 
sesuai instrumen yang telah disiapkan. Selanjutnya observasi dengan pengamatan langsung disertai kajian pada small pilot project pada obyek, sehingga diperoleh beberapa data primer relevan.

\section{Analisis Data}

Alternative strategi bisnis yang digunakan dengan menyesuaikan perubahan lingkungan, situasi organisasi, pemasaran serta persaingan produk berupa analisis Strenghts, Weaknesses, Opportunities, and Threats (SWOT) (Rangkuti, 2019). Tahap kajian riset diawali dengan mengidentifikasi kekuatan dan kelemahan sebagai faktor internal untuk matriks Internal Factor Evaluation (IFE), selanjutnya peluang dan ancaman sebagai faktor eksternal untuk matriks External Factor Evaluation (EFE) pada pengembangan industri kreatif untuk inovasi. Dalam pengambilan keputusan dilakukan pemilihan strategi yang paling tepat menggunakan metode Quantitative Strategic Planning Matrix (QSPM). Perhitungan QSPM didapatkan dari rata-rata bobot masingmasing faktor internal dan faktor eksternal dengan perolehan Total Attractive Score (Zulkarnain et al., 2018). Total Attractive Score dengan nilai terbesar dalam penyusunan strategi berdasarkan factor keberhasilan kunci internal dan eksternal yang telah diidentifikasi sebelumnya sebagai strategi prioritas utama, demikian pula pada urutan prioritas kedua dan selanjutnya.

\section{HASIL DAN PEMBAHASAN}

\section{Analisis Lingkungan Internal}

Usaha Kecil dan Menengah yang menjadi Mitra dari Peneliti yaitu Kelompok Galoeh Bandjar dan Al Firdaus memiliki usaha industri kreatif kerajinan purun yang merupakan tumbuhan khas lahan rawa Kalimantan Selatan. Pengembangan usaha melibatkan sumber daya manusia yang sebagian terbesar para wanita dan ibu rumah tangga. Harapannya dengan kondisi Covid 19, UKM tetap berjalan walaupun menerapkan protokol kesehatan yang ketat serta dapat memberikan strategi terbaik ke depan.

Kekuatan (strength) dan kelemahan (weakness) pada pengembangan industri kreatif untuk indovasi masuk ke dalam lingkungan internal. Identifikasi faktor-faktor yang ada selanjutnya dilakukan analisis lingkungan internal. Hasil analisis matriks Internal Factor Evaluation (IFE) disajikan pada Tabel 1.

Pada Tabel 1 matriks IFE, diketahui total skor terbobot sebesar 2,823 pada pengembangan industri kreatif untuk inovasi, dimana nilai ini berada di atas nilai 2,50. Hal ini menunjukkan bahwa pengembangan industri kreatif untuk inovasi mampu memanfaatkan kekuatan yang dimiliki dan cukup baik dalam mengatasi kelemahan yang ada. Menurut Rangkuti (2019) jika rata-rata total skor masingmasing variabel matriks IFE adalah 2,50 menandakan bahwa posisi internal lemah dan nilai diatas 2,50 menunjukkan posisi internal yang kuat.

Industri kreatif dalam pengembangannya berdampak positif untuk regenerasi perkotaan, pembangunan ekonomi, dan penciptaan lapangan kerja suatu kawasan. Pertumbuhan industri kreatif terkait dengan restrukturisasi ekonomi yang menyebabkan basis ekonomi kota telah bergeser dari manufaktur ke industri padat pengetahuan dan berbasis jasa. Beberapa Negara berusaha untuk meningkatkan daya saing di lingkungan global dan mendapatkan kesempatan menuju ekonomi kreatif.

Tabel 1. Hasil analisis matriks IFE pengembangan industri kreatif untuk inovasi

\begin{tabular}{|c|c|c|c|c|}
\hline No. & Faktor Internal & Bobot & Rating & Skor \\
\hline $\mathbf{A}$ & Kekuatan & & & \\
\hline 1 & Ketersediaan sumber daya alam terbarukan sebagai bahan baku. & 0,180 & 3,50 & 0,630 \\
\hline 2 & Kedua Mitra (UKM) menyadari perlunya standarisasi produk. & 0,088 & 3,00 & 0,264 \\
\hline 3 & Memahami Perlunya Kemitraan secara berkelanjutan. & 0,080 & 3,00 & 0,240 \\
\hline 4 & $\begin{array}{l}\text { Tenaga pekerja wanita yang tersedia dan memiliki waktu jeda } \\
\text { setelah kesibukan rutin sebagai ibu Rumah Tangga. }\end{array}$ & 0,160 & 3,25 & 0,520 \\
\hline 5 & $\begin{array}{l}\text { Potensi alam yang mensupport tumbuh subur komoditas yang } \\
\text { menjadi bahan baku dasar. }\end{array}$ & 0,120 & 3,50 & 0,420 \\
\hline B & Kelemahan & & & \\
\hline 1 & Masih banyak bahan yang terbuang dalam proses produksi. & 0,128 & 2,50 & 0,320 \\
\hline 2 & $\begin{array}{l}\text { Efektifitas waktu untuk suatu produk tertentu belum diketahui lama } \\
\text { produksinya. }\end{array}$ & 0,124 & 2,25 & 0,279 \\
\hline \multirow[t]{2}{*}{3} & $\begin{array}{l}\text { Masih sangat sedikit }(<5 \%) \text { anggota UKM yang melaksanakan } \\
\text { standarisasi secara menyeluruh dan berkelanjutan. }\end{array}$ & 0,120 & 1,25 & 0,150 \\
\hline & Total & 1,000 & & 2,823 \\
\hline
\end{tabular}

Sumber : Data primer diolah, 2020. 
Menurut Booyens (2012) industri yang memanfaatkan kreativitas, inovasi dan keterampilan yang dimiliki seseorang dalam menghasilkan ide, gagasan ataupun produk yang dihasilkan merupakan industri kreatif yang mengarah pada Usaha Mikro Kecil Menengah (UMKM) terkait dengan produksi, distribusi, pertukaran serta konsumsi produk atau jasa. Peran industri kreatif dalam pembaruan kota kreatif, dan implikasinya terhadap pembangunan sosial dan kebijakan.

Sumberdaya merupakan peran utama dalam industri kreatif, dengan demikian pembangunan industri kreatif Indonesia yang kompetitip dilandasi Sumber Daya Manusia (SDM) yang terampil, terlatih, berpengetahuan dan memiliki kreativitas. Didukung dengan obyek dan daya tarik destinasi sub sektor industri berbasis kerajinan di Kampung Purun, Kelurahan Palam, Kecamatan Cempaka, Kota Banjarbaru, Provinsi Kalimantan Selatan yang memiliki kekhasan potensi alam local yaitu kerajinan anyaman purun yang berbahan tanaman purun yang diproduksi menjadi tikar, tas, pelapis pot tanaman, sajadah sholat, hiasan dinding serta berbagai aneka kreasi lainnya.

\section{Analisis Lingkungan Eksternal}

Peluang (opportunities) dan tantangan (threats) pada pengembangan industri kreatif untuk inovasi diidentifikasi ke dalam lingkungan eksternal. Faktor eksternal yang ada selanjutnya di identifikasi dengan analisis matriks External Factor Evaluation (EFE) disajikan pada Tabel 2.

Hasil perhitungan pada Tabel 2 matriks EFE, didapatkan total skor terbobot pada pengembangan industri kreatif untuk inovasi sebesar 2,560 yaitu di atas niali 2,50. Hal ini menunjukkan bahwa pengembangan industri kreatif untuk inovasi mampu memanfaatkan peluang untuk mengatasi tantangan. Menurut Rangkuti (2019) industri telah merespon peluang yang ada di sekitar dengan menghindari ancaman dipasar industrinya. Menurut Lestariningsih et al. (2017) tiga dimensi dalam pembangunan berkelanjutan antara lain pertumbuhan ekonomi, pembangunan sosial dan kelestarian lingkungan. Pengembangan industri kreatif memberikan kontribusi positif pada iklim bisnis, penciptaan inovasi, dan pembentukan kreativitas yang didukung dari segi (1) SDM sebagai modal dasar, (2) Industri, (3) Teknologi, (4) Sumber daya, (5) Institusi, dan (6) Lembaga keuangan. Di sampig itu peran bisnis dan peran pemerintah sangat diperlukan untuk mendukung dan mengembangkan industri kreatif pada UMKM.

Kesiapan Sumber Daya Manusia (SDM) merupakan modal besar yang menjadi faktor kunci dalam pengembangan industri kreatif untuk menghadapi persaingan dengan industri lain di era Industri 4.0. Penciptaan SDM melalui pendidikan, pelatihan serta pendampingan diharapkan mampu dalam percepatan pengembangan ekonomi kreatif yang berkelanjutan dan inovatif. Ekonomi kreatif di Indonesia mencakup 16 industri kreatif: (1) Arsitektur; (2) Desain interior; (3) Desain komunikasi visual; (4) Desain produk; (5) Film, animasi dan video; (6) Fotografi; (7) Kerajinan; (8) Seni kuliner; (9) Musik; (10) Mode; (11) Pengembangan aplikasi dan game; (12) Penerbitan; (13) Periklanan; (14) Televisi dan radio; (15) Seni pertunjukan; dan (16) Seni rupa. Ke-16 industri ekonomi kreatif Indonesia diukur dengan menggunakan standar siklus hidup survei, yang dimulai dari penghubung klien, perencanaan, pengembangan survei, desain sampel, pengumpulan data, pengolahan, estimasi, analisis, diseminasi, dan evaluasi. Pengumpulan data yang dihasilkan bermanfaat untuk mendeskripsikan kontribusi ekonomi kreatif terhadap pembangunan berkelanjutan, khususnya dalam mendukung tujuan pembangunan berkelanjutan (Lestariningsih et al., 2018).

Tabel 2. Hasil analisis matriks EFE pengembangan industri kreatif untuk inovasi

\begin{tabular}{clccc}
\hline No. & \multicolumn{1}{c}{ Faktor Eksternal } & Bobot & Rating & Skor \\
\hline $\mathbf{A}$ & Peluang & & & \\
1 & Kebijakan dan Regulasi saat Pandemi Covid 19 & 0,100 & 2,00 & 0,200 \\
2 & Dukungan dan sinergitas Pentahelix dalam Program Kemitraan & 0,153 & 3,25 & 0,497 \\
3 & Market share untuk perubahan pasar yang cepat & 0,127 & 3.50 & 0,445 \\
4 & Terdapat beberapa objek wisata disekitar daerah UKM & 0,097 & 1,75 & 0,170 \\
5 & Dekat dengan pusat kota & 0,073 & 1,75 & 0,128 \\
B & Tantangan & & & 0,326 \\
1 & Persaingan antara UMKM & 0,087 & 3,75 & 0,105 \\
2 & Peningkatan kualitas SDM untuk membuat diversifikasi produk. & 0,060 & 1,75 & 0,275 \\
3 & Membangun jaringan penguat untuk pengembangan Teknologi & 0,100 & 2,75 & 0,219 \\
4 & Informasi & 0,125 & 1,75 & 0,195 \\
\hline & Membangun kolaborasi Pentahelix guna penguatan dan & 0,078 & 2,50 & $\mathbf{2 , 5 6 0}$ \\
\hline
\end{tabular}

Sumber : Data primer diolah, 2020. 
Menurut Alexandri et al. (2019) pengembangan ide dan kreatifitas yang dihasilkan Industri sangat tergantung pada teknologi, dimana SDM memiliki kemampuan dalam mengaplikasikan teknologi tersebut. Pada rantai kreasi Industri kreatif Information and Communication Technology (ICT) digunakan untuk memperoleh, menyebarkan dan melakukan pertukaran informasi dan memperkaya ide kreasi. Pada rantai distribusi dan komersialisasi penggunaan ICT dalam proses transaksi dan promosi.

Dalam melakukan inovasi perlu dilakukan proses menciptakan nilai tambah, ide, dan kreativitas yang dimilik oleh sumber daya alam maupun kesediaan lahan yang menjadi input penunjang industri kreatif kerajinan anyaman purun. Pemanfaatan sumber daya alam yang tersedia dilakukan secara optimal dengan tetap mengikuti pola pikir ranah lingkungan. Produk anyaman purun merupakan kerajinan warisan budaya yang dapat dilatihkan kepada generasi muda sehinggan produk anyaman purun tidak punah dan bisa berkembang dikalangan remaja sebagai pewaris budaya bangsa.

\section{Perumusan dan Penetapan Solusi Pengembangan Industri Kreatif untuk Inovasi}

Matriks Internal-Eksternal (IE) merupakan pemetaan matriks diperoleh dari matriks Internal Factor Evaluation (IFE) dan matriks External Factor Evaluation (EFE). Nilai IFE terbobot sebesar 2,823 dan nilai EFE terbobot sebesar 2,560 yang dapat diplotkan dalam matriks Internal-Eksternal yang dapat dilihat pada Gambar 1.

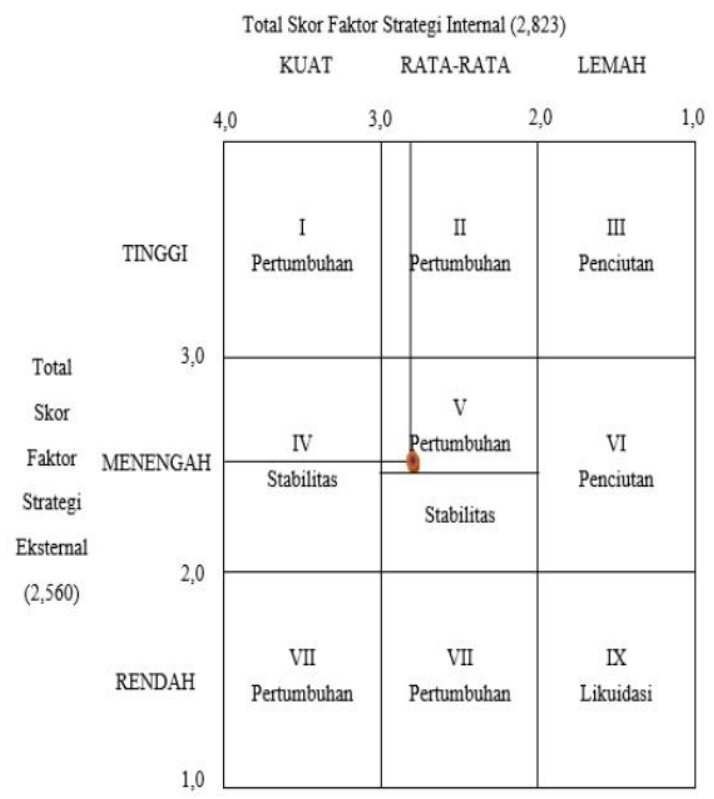

Gambar 1. Matriks Internal-Eksternal potensi pengembangan industri kreatif untuk inovasi
Berdasarkan Gambar 1, posisi ini menunjukkan industri berposisi pada sel $\mathrm{V}$ yang menunjukkan bahwa industri saat ini tahap pertumbuhan dan perkembangan, sehingga strategi yang dapat diimplementasikan industri dari matriks IE yaitu strategi penetrasi pasar, pengembangan produk dan pengembangan pasar. Hal ini dapat dicapai dengan strategi memperluas market share melalui peningkatan kegiatan pemasaran/ promosi, dan pengembangan produk dengan cara meningkatkan kualitas produk, inovasi produk kemasan ekonomis agar dapat dijangkau konsumen, dan inovasi pengembangan produk baru.

Berdasarkan hasil penelitian Budiono (2017) dalam tahap tumbuh dan kembang, perusahaan dalamhalini UMKM dapat melakukan strategi penetrasi pasar, pengembangan pasar dan pengembangan produk atau strategi integratif seperti integrasi ke belakang, integrasi ke depan dan integrasi horizontal. Integrasi ke depan berarti mendapatkan kepemilikan atau kendali yang lebih besar atas distributor atau perwakilan. Integrasi ke belakang berarti mencari kepemilikan atau kendali pemasok yang lebih besar. Integrasi horizontal mencari kepemilikan atau kendali yang lebih besar atas pesaing.

Mitra Kelompok Pengrajin Purun Galoeh Bandjar dan Kelompok Pengrajin Purun Al Firdaus di Kelurahan Palam memiliki produk bervariasi didukung regenerasi pengrajin anyaman dan memudahkan dalam hal pengembangan pembuatan kerajinan yang menghasilkan sebuah kerajinan secara berkelanjutan dengan memperhatikan trend disertai dengan Unique Selling Proposition (USP) yang penting dibandingkan dengan pesaing. Hal tersebut sejalan dengan Jodi et al. (2019), dimana sektor industri kreatif tergolong unik karena sangat bertumpu pada kreativitas dan daya inovasi Sumber Daya Manusia (SDM) dalam proses produksinya. Hampir semua produk yang ditawarkan sektor industri sub kreasi bergantung pada pesanan, selera masyarakat, dan trend. Hal tersebut tentunya mencakup kreativitas, ide, dan inovasi para pekerja di dalamnya untuk menghasilkan produk yang sesuai selera pasar. Pola pikir yang inovatif dan modern adalah usaha untuk meningkatkan kreativitas demi perkembangan dan kesuksesan industri kreatif kerajinan anyaman purun dapat memproduksi suatu produk dengan berbagai bentuk dengan kualitas yang lebih baik.

Cara yang sudah dilakukan Mitra Kelompok Pengrajin Purun Galoeh Bandjar dan Al Firdaus yaitu mempromosikan hasil-hasil kerajinannya melalui website, media sosial (instagram) dan juga dengan pemberian label nama kelompok dan penerapan standarisasi mutu produk.

Sumber : Data primer diolah, 2020 


\section{Matriks Strenght, Weakness, Opportunities, and Threats (SWOT)}

Hasil analisis dari faktor internal dan faktor eksternal selanjutnya dilakukan penyusunan beberapa alternatif strategi mengacu analisis Strenght, Weakness, Opportunities, and Threats (SWOT) yang disajikan pada Tabel 3.

Tahap penyesuaian antara kekuatan dan kelemahan terhadap peluang dan ancaman untuk mendapatkan alternatif strategi dengan menggunakan matriks SWOT adalah bagian yang harus dicermati dengan baik (Rusdiansyah, 2016). Pada tahap matching stage melaui Matriks SWOT dan Matriks IE, diperoleh alternative strategi yang akan diimplementasikan industri kreatif untuk mengatasi kelemahan dan menghindari ancaman atau tantangan yang ada. Hasil alternatif strategi yang harus dilakukan sesuai dengan hasil matriks SWOT untuk pengembangan industri kreatif untuk inovasi adalah :

1. Meningkatkan ketersediaan sumber daya potensial (SO)

2. Meningkatkan kualitas produk terstandar dan berkelanjutan (SO)

3. Mengembangkan prinsip efisiensi untuk daya saing (WO)

4. Membangun kemitraan (ST)

5. Mengendalikan/mengelola perubahan pasar dengan cepat (WT)

Tabel 3. Matriks SWOT pengembangan industri kreatif untuk inovasi

\begin{tabular}{|c|c|c|}
\hline Faktor Internal & $\begin{array}{c}\text { Kekuatan } \\
\text { (Strengths) }\end{array}$ & Kelemahan (Weaknesses) \\
\hline Faktor Eksternal & $\begin{array}{l}\text { 1. Ketersediaan sumber daya alam } \\
\text { terbarukan sebagai bahan baku } \\
\text { 2. Kedua Mitra (UKM) menyadari } \\
\text { perlunya standarisasi produk. } \\
\text { 3. Memahami perlunya kemitraan } \\
\text { secara berkelanjutan } \\
\text { 4. Tenaga kerja wanita yang } \\
\text { tersedia dan memiliki waktu jeda } \\
\text { setelah kesibukan rutin sebagai } \\
\text { Ibu Rumah Tangga. } \\
\text { 5. Potensi alam yang } \\
\text { mendukung tumbuh subur } \\
\text { komoditas yang menjadi bahan } \\
\text { baku dasar. }\end{array}$ & $\begin{array}{l}\text { 1. } \begin{array}{l}\text { Masih banyak bahan yang } \\
\text { terbuang dalam proses } \\
\text { produksi }\end{array} \\
\text { 2. Efektifitas waktu untuk suatu } \\
\text { produk tertentu belum } \\
\text { diketahui lama produksinya } \\
\text { 3. Masih sangat sedikit }(<5 \%) \\
\text { anggota UKM yang } \\
\text { melaksanakan standarisasi } \\
\text { secara menyeluruh dan } \\
\text { berkelanjutan. }\end{array}$ \\
\hline $\begin{array}{c}\text { Peluang } \\
\text { (Opportunities) }\end{array}$ & Strategi SO & Strategi WO \\
\hline $\begin{array}{l}\text { 1. Kebijakan dan Regulasi saat } \\
\text { Pandemi Covid } 19 \\
\text { 2. Dukungan dan sinergitas } \\
\text { Pentahelix dalam Program } \\
\text { Kemitraan } \\
\text { 3. Market share untuk perubahan } \\
\text { pasar yang cepat } \\
\text { 4. Terdapat beberapa objek wisata } \\
\text { di sekitar daerah UKM. } \\
\text { 5. Dekat dengan pusat kota }\end{array}$ & $\begin{array}{ll}\text { - } & \text { Meningkatkan ketersediaan } \\
\text { sumber daya potensial } \\
\left(\mathrm{S}_{1,3,5}-\mathrm{O}_{2,3,4}\right) \\
\text { - } \\
\text { Meningkatkan kualitas } \\
\text { produk terstandar dan } \\
\text { berkelanjutan } \\
\left(\mathrm{S}_{2,4}-\mathrm{O}_{1,5}\right)\end{array}$ & 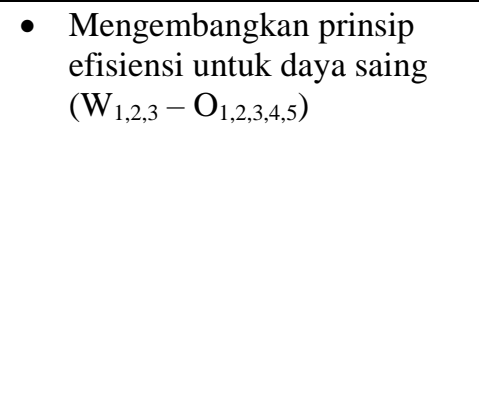 \\
\hline $\begin{array}{l}\text { Tantangan } \\
\text { (Threats) }\end{array}$ & Strategi ST & Strategi WT \\
\hline $\begin{array}{l}\text { 1. Persaingan antara UMKM } \\
\text { 2. Peningkatan kualitas SDM untuk } \\
\text { membuat diversifikasi produk. } \\
\text { 3. Membangun jaringan penguat } \\
\text { untuk pengembangan Teknologi } \\
\text { Informasi. } \\
\text { 4. Standarisasi Mutu } \\
\text { 5. Membangun kolaborasi } \\
\text { Pentahelix guna penguatan dan } \\
\text { pengembangan Teknologi } \\
\text { Informasi. }\end{array}$ & $\begin{array}{l}\text { Membangun kemitraan } \\
\left(\mathrm{S}_{1,2,3,4,5}-\mathrm{T}_{1,3,5}\right)\end{array}$ & $\begin{array}{l}\text { Mengendalikan/mengelola } \\
\text { perubahan pasar dengan cepat } \\
\left(\mathrm{W}_{1,2,3}-\mathrm{T}_{2,4}\right)\end{array}$ \\
\hline
\end{tabular}

Sumber : Data primer diolah, 2020. 


\section{Analisis Quantitative Stategic Planing Matrix (QSPM)}

Analisis selanjutnya yang digunakan untuk pengambilan keputusan dalam menentukan prioritas strategi utama, kedua, ketiga dan seterusnya adalah Quantitative Stategic Planing Matrix (QSPM). Strategi pada Matriks QSP disusun melalui matriks IE dan analisi SWOT yang telah didapatkan sebelumnya, maka dapat ditentukan strategi yang terbaik bagi pengembangan industri kreatif untuk inovasi yang disajikan pada Tabel 4.

Hasil analisis Quantitative Strategic Planing Matrix (QSPM) untuk strategi pengembangan industri kreatif untuk inovasi yang menjadi prioritas utama adalah pentingnya ketersediaan sumber daya potensial dengan nilai sebesar 15,862 dilanjutkan dengan urutan kedua hingga ke lima masing-masing adalah perlunya memahami perubahan pasar dengan cepat sebesar 14,840, membangun kemitraan sebesar 14,646 , produk terstandar dan berkelanjutan sebesar 14,123 serta mengembangkan prinsip efisiensi untuk daya saing sebesar 12,288. Nilai Total Attractiveness Scores (TAS) terbesar yaitu 15,862 menunjukkan bahwa strategi tersebut yang harus dilakukan pada jangka pendek ke depan, dengan memberikan keunikan pesona atau daya tarik pada Pengunjung selama kunjungannya di Kampung Purun. Pelanggan yang fanatik dan loyal merupakan bagian dari target USP dan inovasi. Edukasi kreatif yang diberikan juga akan membangun semangan inovasi bagi SDM setempat dan Pengunjung, selain membeli produk secara langsung.

Dalam hal memperkuat branding, edukasi dalam bentuk pelatihan, pembinaan serta contoh langsung bagaimana menghadapi situasi perubahan pasar yang cepat disertai branding yang selalu diingat konsumen (Ananda dan Susilowati, 2017). Di sisi lain, pentingnya kemitraan, standarisasi produk serta senantiasa mengawal efisiensi dalam setiap tahap input,proses, output hingga outcome.

Menurut Winasis dan Setyawan (2016) dalam pemanfaatan sumber daya alam akan bisa optimal maka perlu pengetahuan, ketrampilan, dan kreativitas yang dapat memberikan nilai tambah pada dari sebelumnya, misal rotan, merupakan sumberdaya unik di Indonesia, dapat dibuat produk-produk fisikal seperti desain, kerajinan dan fesyen memberikan identitas nasional yang dibutuhkan dalam berkompetisi di pasar global. Keragaman sumberdaya ala mini dapat dijadikan sebagai bahab baku untuk menghasilkan produk industri kreatif. Keberlanjutan sangat dipengaruhi dengan terbangunnya kemitraan dengan prinsip win-win solution. Menurut Simatupang et al. (2012) knowledge creative (Pengetahuan yang kreatif), skilled worker (pekerja yang berkemampuan), labor intensive (kekuatan tenaga kerja) bagi industri kreatif akan menjadi potensial.

Sinergi pengembangan industry kreatif untuk inovasi dapat dioptimalkan melalui komitmen cendikiawan yang terkait (tokoh, kelompok studi dan peneliti), bisnis dan pemerintah yang dikoordinasikan secara berkesinambungan. Komitmen ini meliputi keterlibatan financial dan non financial. Dalam hal finansial pembiayaan program pengembangan industri kreatif dapat dilakukan melalui APBN, CSR, dan alokasi dana Riset, sedangkan non finansial melalui pelaksanaan administrasi public yang lebih cepat dan efisien, komitmetmen pendidik untuk memberi materi sebaik-baiknya. Selanjutnya membentuk knowledge space bagi industri kreatif dengan menciptakan pertukaran informasi, pengetahuan, skill, teknologi, pengalaman, preferensi lokasi pasar, serta informasi lainnya.

Untuk Pengembangan terkait skill sumber daya manusia, perlu diberlakukan standarisasi kompetensi pengrajin kreatif, peningkatan kreativitas sumber daya manusia untuk menghasilkan produk sesuai permintaan pasar, dan optimalisasi pemanfaatan teknologi dan implementasinya serta tersedia pasar yang kompetitif. Dalam pendidikan formal peran kurikulum penting dalam melahirkan anak bangsa yang mempunyai jiwa entrepreneurship dan kreativitas. Disamping itu untuk mendukung dan melahirkan inovasi ada keterlibatan dari masyarakat, industri, dan instansi pemerintahan terkait dalam mengkoordinasikan kegiatan tersebut dengan pemanfaatan obyek wisata. Selanjutnya untuk mengembangkan prinsip efisiensi dapat dilakukan dengan memaksimalkan sistem quality control, disertai penerapan sistem logistik yang senantiasa memperhatikan ketepatan pesanan, sehingga mampu memberikan kepuasan yang lebih baik baik pagi Pengrajin sendiri, Pelanggan, maupun Vendor yang selama ini sudah bersinergi.

Tabel 4. Analisis matriks QSPM dalam pemilihan alternatif strategi

\begin{tabular}{llcc}
\hline No. & \multicolumn{1}{c}{ Alternatif Strategi } & Total Attractiveness Scores & Peringkat \\
\hline 1. Meningkatkan ketersediaan sumber daya potensial (SO) & 15,862 & 1 \\
2. Meningkatkan kualitas produk terstandar dan & 14,123 & 4 \\
berkelanjutan (SO) & & 5 \\
3. Mengembangkan prinsip efisiensi untuk daya saing (WO) & 12,288 & 3 \\
4. Membangun kemitraan (ST) & 14,646 & 2 \\
5. Mengendalikan/mengelola perubahan pasar dengan cepat & 14,840 & \\
(WT) & & \\
\hline
\end{tabular}

Sumber : Data primer diolah, 2020. 


\section{KESIMPULAN DAN SARAN}

\section{Kesimpulan}

Penelitian dan pengembangan yang dilakukan diperoleh kesimpulan yaitu menggunakan analisis SWOT dan analisis lanjut untuk strategi fokus dengan QSPM diperoleh kesimpulan mengacu total attractiveness scores disertai saran yang dapat diberikan.

Alternatif strategi yang didapatkan dari analisis SWOT sebanyak 5 (lima) strategi. Selanjutnya dilakukan perhitungan nilai ketertarikan total (total attractiveness scores) menggunakan analisis Quantitative Strategic Planning Matrix (QSPM). Hasil analisis memberikan nilai total tertinggi yaitu pada pentingnya ketersediaan sumberdaya potensial dengan nilai sebesar 15,862 dilanjutkan dengan urutan kedua hingga ke lima masing-masing adalah perlunya memahami perubahan pasar dengan cepat sebesar 14,840, membangun kemitraan sebesar 14,646, produk terstandar dan berkelanjutan sebesar 14,123 serta mengembangkan prinsip efisiensi untuk daya saing sebesar 12,288.

\section{Saran}

Untuk mengoptimalkan hasil analisis QSPM sesuai hasil total attractiveness scores yang diperoleh, perlu diperhatikan aktivitas transformasi maupun aktivitas transaksi dalam melayani pemenuhan untuk semua level. Di sisi lain untuk menjaga keberlanjutan tumbuhan purun perlu adanya kolaborasi dengan pengembang usaha pertambangan yang dapat mengoptimalkan lahan pasca tambang mereka, terutama pada wilayah cekungan dan berair dengan mengembangkan purun untuk keberlanjutan program jangka panjang.

\section{UCAPAN TERIMA KASIH}

Tim Pengabdian Kepada Masyarakat penerima pendanaan Program Teknologi yang di Desiminasikan ke Masyarakat (PTDM) Tahun 2020 mengucapkan terima kasih kepada DPRM Kemenristek/BRIN, Deputi Bidang Penguatan Riset dan Pengembangan atas disetujuinya Proposal dan diberikan pendanaan untuk pelaksanaan kegiatan pengabdian.

\section{DAFTAR PUSTAKA}

Ananda AD dan Susilowati D. 2017. Pengembangan usaha mikro kecil dan menengah (UMKM) berbasis industri kreatif di kota malang. Jurnal Ilmu Ekonomi. 1(1): 120-142.

Anggito A dan Setiawan J. 2018. Metodologi Penelitian Kualitatif. Cetakan Pertama, CV Jejak. P1-268.

Alexandri MB, Zultaqawa Z, dan Aulia MD. 2019. Creative industries: Strategy and challenges in the Craft Sub-sector. Review Integrative Business and Economics Research. 8(4): 255263.

Booyens I. 2012. Creative industries, inequality and social development: developments, impacts and challenges in Cape Town. Urban Forum, 23 (1): 43-60.

Budiono GL. 2017. Mapping and selecting company's competitive strategy. European Research Studies Journal. XX (4A): 696-706.

Direktorat Jendral Perhubungan Darat. 2020. Tantangan industri logistik dalam masa Pandemi COVID-19. Webinar Transportasi dan Logistik Saat dan Pasca Pandemi Covid19 di Indonesia. Jakarta:10 Juni 2020.

Elrhim MA dan Elsayed A. 2020. The effect of COVID-19 spread on the E-commerce market: The case of the 5 Largest E-commerce companies in the World. SSRN-Elsevier. 1-14, http://dx.doi.org/10.2139/ssrn.3621166

Jodi NS, Sudjadi A, dan Anggraeni AI. 2019. The role of creativity in forming innovative behaviours of creative industrial workers. International Journal Innovation, Creativity and Change. 11(9): 166-178.

Kozlenkova IV, Hult GTM, Lund DJ, Mena JA, Kekec P. 2015. The role of marketing channels in supply chain management. Journal Retailing. 91(4): 586-609.

Lestariningsih E, Maharani K, dan Lestari TK. 2018. Measuring creative economy in Indonesia: issues and challenges in data collection. AsiaPacific Sustainable Development Journal. 25(2): 99-114.

Lestariningsih E, Gusnisa S, dan Maharani K. 2017. Legal setting for the development of interagency sectoral statistics database (ISSD). Asia-Pacific Economics Statistics Week, 22 - 26 May 2017. BPS-Statistics Indonesia, Jakarta.

Rangkuti F. 2019. Teknik Membedah Kasus Bisnis Analisis SWOT: Cara Perhitungan Bobot, Rating dan OCAI. Cetakan xiii. Jakarta : PT. Gramedia Pustaka Utama. P1-246.

Rusdiansyah R. 2016. Analisis strategi aplikasi penagihan dengan Metode SWOT. Bina Insani ICT Journal. 3(1): 145-153.

Saragih NI, Hartati V, dan Fauzi M. 2020. Tren, tantangan, dan perspektif dalam sistem logistik pada masa dan pasca (New Normal) Pandemik Covid-19 di Indonesia. Jurnal Rekayasa Sistem Industri. 9(2): 77-86.

Saqib ZA, Saqib KA, dan Ou J. 2019. Role of visibility in supply chain mnagement. Modern Perspectives in Business Applications. IntechOpen. 9-19.

Simatupang TM, Rustiadi S, dan Situmorang DBM. 2012. Enhancing the Competitiveness of the Creative Services Sectors in Indonesia in Tullao TS and Lim HH (eds.), Developing 
ASEAN Economic Community (AEC) into A Global Services Hub. ERIA. P173-270.

Winasis A dan Setyawan D. 2016. Efektivitas program pengembangan desa wisata melalui kelembagaan dalam peningkatan sumber daya alam (SDA). Jurnal Ilmu Sosial dan Ilmu Politik. 5(2): 12-16.
Zulkarnain A, Wahyuningtias D, dan Putranto TS. 2018. Analysis of IFE, EFE and QSPM matrix on business development strategy. IOP Conference Series: Earth and Environmental Science. 126 (1): 1-7. doi:10.1088/17551315/126/1/012062 